\title{
LEARNING COMPETENCIES AND POSSIBILITIES OF THEIR DEVELOPMENT IN MILITARY PROFESSIONALS
}

\author{
L'ubomír Kubínyi ${ }^{1}$, Radomír Saliger ${ }^{2}$ \\ ${ }^{1}$ Department of Resource Management, Faculty of Military Leadership, University Defence, Kounicova 65, \\ 66210 Brno, Czech Republic \\ ${ }^{2}$ Department of Leadership, Faculty of Military Leadership, University Defence, Kounicova 65, 66210 Brno, \\ Czech Republic
}

Link to this article: https://doi.org/10.11118/actaun.2021.019

Received: 16. 6. 2020, Accepted: 26. 2. 2021

To cite this article: KUBÍNYI L'UBOMÍR, SALIGER RADOMÍR. 2021. Learning Competencies and Possibilities of Their Development in Military Professionals. Acta Universitatis Agriculturae et Silviculturae Mendelianae Brunensis, 69(2): 221-229.

\begin{abstract}
The contribution is aimed at describing the importance of competencies in the lifelong learning processes, the definition of the concept of competency and the components of a learning competency. On the basis of the above-mentioned theoretical approaches, it identifies the possibility of using the most current approaches to increase the measure of efficiency of educational and training processes in military professionals of the Army of the Czech Republic. A system of further education has been created in the Army of the Czech Republic, which is designed as a system of various courses, trainings, stays abroad and other activities. These are formulated in the concept of staff development, which allows the staff to actively approach their self-development. Part of the paper describes the project investigating some aspects of motivation to learning in military professionals and the selected results acquired using the quantitative research method.
\end{abstract}

Keywords: army of the Czech Republic, competencies, learning competencies, conceptualization, development, education, military professionals, research project

\section{INTRODUCTION}

The ability to learn should be developed in each individual and each individual should assume responsibility for its development. Its foundations are already laid during school attendance and its further development occurs not only in formal education, but also in the environment of employers' organizations after the entry into the labour market. Competencies are thus the aim of interests not only of the experts focused on the development of theory, but increasingly they are also given increased attention from the viewpoint of their practical use, especially in the field of human resource management.

The theoretical starting points of the research were the concept of lifelong learning (Průcha and
Veteška, 2014) and the theory of motivation. The sociological approach to motivation considers attitudes to be key motives (Dvořáková, 2007) and human behaviour can be predicted and measured to a certain extent (Hendl, 2005). The presumption was that each military professional had specific training needs. However, the training needs mentioned do not have to necessarily be in accordance with the requirements for the training profile of a military professional assigned to a service post within the Ministry of Defence. The requirement to perform the most demanding service activities within the service post relates to the requirements for qualification prerequisites (educational attainment level) and qualification requirements (career, language and specialized courses). The sample of 
respondents consisted of a total of 439 professional soldiers within the units of the Army of the Czech Republic. A semi-standardized questionnaire containing a total of 21 questions was used for the measurement. The data was statistically processed and subsequently interpreted. The paper presents only selected results of the research done. From the viewpoint of motivation, we consider the superior's support to be a significant factor for participation in further professional training. Therefore, it is important that a total of $68 \%$ of respondents state that they have the superiors' support for further professional training and 58\% of respondents state that the superior creates conditions for their participation in courses. The factor that influences the participation of adults in educational activities is the level of awareness of the offer of educational activities. Only a total of $28 \%$ of respondents say they have information about the educational offer. Another area of the research was to identify the most important obstacles to the involvement in further professional training. A total of $36 \%$ of respondents state that the most important obstacle is a lack of time, the disagreement of the superior (30\%) and the impossibility of applying knowledge and skills (22\%). In accordance with the needs of the Ministry of Defence and based on the requirements of the administrators of military fields and qualifications, the existing educational and training activities are continuously updated and the new ones are created with the aim to maintain consistency between the training content and practice needs in cooperation with the management of the Ministry of Defence (Concept, 2019). This fact may be a source of the above-mentioned opinions and attitudes of respondents in relation to evaluating the offer and supporting education, when respondents' subjective requirements differ in relation to the requirements of the Ministry of Defence for their training. The staff training system is developed primarily in accordance with the objectives and priorities set by the conceptual, strategic and planning documents of the Ministry of Defence. Emphasis is placed on linking theory to practice aimed at the development of capabilities and skills to safeguard the defence of the Czech Republic and to meet the Alliance commitments; conditions are created for sharing capabilities and experts in training the staff with foreign partners (Concept, 2019).

\section{Theoretical Background of the Study}

The definition of a competency as a multidimensional construct is diverse. Some definitions accentuate characteristics and other behaviour; however, it can be said that it is possible to follow the definition of learning competencies through characteristics and components.

From the sociological point of view, the concept of competency is used as a given power to make decisions. The second meaning is related to the ability to perform a certain activity, to be qualified, which implies that the individual has achieved a specified level of knowledge and skills that support the achievement of a qualified performance.

Competency as capability was already described in 1982 by R. Boyatzis in The Competent Manager: A Model for Effective Performance. The author emphasized the difference between the task to be accomplished and the abilities and other qualities that a worker must have to accomplish the task at a desired level. "Competency is a set of behaviours a worker has to use in a given position in order to be able to handle tasks from that position competently.” (Kubeš et al., 2004, p. 27).

Competencies "relate to specific areas of requirements" and the question "Competent for what?" is an essential part of any definition of the concept of competency (Klieme et al., 2010). Perrenoud (1997 in Skalková, 2007) defines competencies as an ability to act effectively in a certain type of situations, a knowledge-based ability, which is not limited to them only. According to Klieme et al. (2010), defining the context from the viewpoint of areas of situations and requirements is of critical importance. The key competencies are the competencies, skills that are necessary for an individual to keep his/her job in the course of his/ her life and to be able to become involved not only in a personal, but also social life. The concept of key competencies is described by Mertens (cf. Belz and Siegriest, 2015); through this title he defines the competencies that help to cope with reality and to cope with the requirements of a dynamically changing labour market.

A higher level of motivation to education can show itself in the quality and quantity of employee work performance. Vodák and Kucharčíková (2007) list the motivation factors of education. Through education, an individual can improve his/her position in a group, can strive for career advancement with a greater degree of success on the basis of increasing the quality and quantity of work, increasing the flexibility and readiness for changes, gaining social benefits, a higher salary and also applying his/her own potential for new opportunities.

When exploring adults' motivation to education, it is important to deal not only with the personality traits of the participants, but also with the procedures and tools that stem from the external resources of the organization. In the attitudes of adults to education, three psychological characteristics can be observed - motivation, need and interest (Průcha, 2014). The level of motivation of individual participants in education is divergent. It depends on the organizational culture, which supports the development of employees in an optimal case. It is important for the saturation of the said characteristics how the need for training in the organization is identified, how active the 
involvement of employees is, and to what extent and how the organization meets individual educational needs. In practice, the procedure proves useful when the managerial staff communicate their visions, procedures, values and standards, which can provide better mutual awareness of a range of professional, organizational, personnel, economic or specifically educational issues.

\section{Definition of a Learning Competency}

In recent years, the topic of pedagogical theory and practice has been a discussion of the need to modify traditional educational objectives. The new concept of objectives has a different form and designation. The attempts of many authors to define new educational objectives may be mentioned (Chvál and Straková, 2014).

In general, the definition of a learning competency is based on a context-based approach to learning. It includes not only "know what", but in particular "know how" and also "know why" (Crick, 2007 in Lokajíčková, 2013). It should be noted that learning competencies are perceived as a disposition for coping with learning situations. Based on the analysis of existing models, Stringer has developed the definition of the "learning to learn" competency as "an effective learning management process that represents the ability to deeply engage in learning that continually increases the skill to control the style, time and place of learning itself. This process evolves into an evolving lifelong career with the ultimate goal of understanding reality" (Chvál and Straková, 2014).

A learning competency is part of the concept of lifelong learning, allowing the maximum use of the human potential, which is perceived as a necessary process leading to successful exercise in the labour market. Lifelong learning is based on quality basic education, which should "teach individuals to learn" and "have a positive attitude towards learning” (Veteška and Tureckiová, 2008).

\section{Developing a Learning Competency in the Military Profession}

The military profession is a specific profession that differs from other professions from the viewpoint of the type of activities. According to Huntington, the military profession is differentiated by a specialized expert knowledge that he calls "the management of violence". The officers also differ by technical, military and social knowledge, due to which they are able to lead their subordinates and fulfil assigned tasks in accordance with the type of activity (Field Manual No. 22-100). Authoress Kirchhoff who dealt with the issues of promoting the development of officers' competencies emphasizes that with each next generation it is necessary to revise the knowledge and assess whether it corresponds to the cultural and social development of society (1997). Similar considerations are also associated with the dynamic development in military affairs, when the definitions of modern combat, the concept of combat power and the change in the role of armies in peacetime are being reappraised (Razma, 2019). The said approaches to the redefinition of underlying concepts are also related to the changes to the training processes and the development of military professionals, both from the viewpoint of educational content and from the viewpoint of the use of modern technologies or the use of inspirations from the management of educational processes in the most progressive civilian organizations. Increasing the measure of effectiveness of education can be achieved, e.g. by using computer-aided learning applications (Smaliukienè et al., 2011), by using coaching (Rosha et al., 2015), and by public-private partnerships in military training (Dubauskas et al., 2015). We consider the approaches to assessing the eligibility for military service in the Lithuanian Armed Forces to be inspiring (Raudeliūnienè et al., 2013) as well as the eligibility assessment model developed for the Lithuanian Navy officers (Prakapienè and Petronis, 2015).

A subsystem of further professional education in the Czech Republic is the personnel training system within the Ministry of Defence. The training system is based on the concept of lifelong learning and contains interconnected processes of education and training. The aim is to prepare a military professional who is a qualified expert in a voluntary employment relationship, is educated in the military affairs and specially trained for military practice (Training Concept, 2011). The current concept of personnel training is based on the premise that the qualification requirements and prerequisites set for individual service posts stem strictly from the needs of the Ministry of Defence and are linked to the career management system. The characterization of service posts is determined according to the actual needs of the Ministry of Defence and is determined by the qualification prerequisites and requirements for individual categories of personnel. The internal legal regulations of the Ministry of Defence set basic qualification requirements for individual rank categories at each command and control level, foreign language knowledge, and special requirements arising from military expertise and specializations (Concept, 2019). It can be stated that these activities are aimed at the future rather than the present in terms of time (Čirjevkis, 2015).

The systematic training of military personnel results from the concept of lifelong learning and the main elements of the process are education and training of the military professional who is a qualified expert in the voluntary employment relationship, is educated in the military affairs and specially trained for military practice (Training Concept, 2011). An important factor, which affects training effectiveness, is the level of an individual's 
motivation to learn. Another important factor of engaging military professionals in the processes aimed at the development of competencies is awareness of educational opportunities. The research conducted in 2015 that took place in the respondents of the Lithuanian Armed Forces and the Austrian Armed Forces highlights the importance of information. A total of $92 \%$ of the Austrian Armed Forces respondents and 71\% of the Lithuanian Armed Forces respondents stated that they had information on educational opportunities (Hurbišová and Davidová, 2016).

The essence of desirable behaviour in the military affairs is a motivated and proactive military professional who is identified with the goals, visions and tasks of the organization. He/she perceives the positive elements of the organizational culture, is interested not only in the results of his/her work, but also in influencing the results of team members. $\mathrm{He} /$ she supports the activity of the others and in this way he/she develops a positive climate within the unit or, if need be, within the organization; he/she is interested in further self-education and cooperates with the other members of the unit.

\section{MATERIALS AND METHODS}

\section{Research Project}

In recent years, the work team of the Department of Leadership at the Faculty of Military Leadership of the University of Defence in Brno has dealt with the development of military professionals' competencies. The research was carried out from 2016 to 2019 within the Sub-Intention of Organizational Development. One of the research objectives was to identify the respondents' opinions and attitudes to motivation for participation in further professional education. The theoretical starting points of the research project were the concept of lifelong learning and the rational choice theory.

The research was based on a sociological approach to motivation, which considers attitudes to be the representatives of key motives (Dvořáková, 2007) and according to Hendl (2005), human behaviour can be measured and predicted to some extent. When deciding whether to enter further education, the individual compares the value of education with the cost of its achievement.

\section{Research Tool to Measure Competency}

A semi-standardized structured questionnaire containing a total of 21 questions was used for the measurement. Respondents had a choice of several options for each question.

The questionnaire mainly measures the degree of respondents' self-activity for further education, motivation to learning and the level of superiors' support for further education; it specifies the reasons, which respondents consider to be decisive for their participation in further professional education, the obstacles to their involvement in further professional education and the willingness to devote time to further professional development. As for the questions, both the system of rating scale questions and the choice of an answer from the options offered were used and the respondents answered yes or no to the sub-questions.

\section{Sample of Respondents}

The sample of respondents was created by the soldiers of the Army of the Czech Republic present based on their availability within the units of the Army of the Czech Republic. A total of 439 respondents were addressed. A total of 1 senior officer, 86 junior officers, 62 warrant officers, 201 non-commissioned officers and 88 enlisted men participated in the research.

\section{Methodology of Data Collection}

The data collection was carried out in agreement with the unit commanders of the Army of the Czech Republic; these units are essential for meeting the requirements of the Army of the Czech Republic. They are in compliance with the requirements imposed on the Army of the Czech Republic within the membership of the Czech Republic in NATO. The face-to-face data collection was performed by two members of the research team who, after their arrival at the units of the Army of the Czech Republic and at the beginning of the data collection, explained in detail the essence of the research, the way of completing the questionnaires, the timeframe and other details. During data collection anonymity was ensured, inter alia, by allocating the places to respondents. No data was required in the questionnaire that would identify a particular respondent according to his/her name. After completing the questionnaire, another researcher collected completed questionnaires for further processing. In neither case did the respondent refuse to complete the questionnaire for any reason. In conclusion, the researchers thanked respondents for their responsible approach to the realization of the research. They said that respondents would be acquainted with the results after their processing.

\section{RESULTS}

\section{Selected Research Results and Their Interpretation}

Development support is one of the very important factors for motivation to further professional education. The results are presented in Fig. 1 and Fig. 2. It ensues from the research results that a total of $32 \%$ of respondents do not feel their superiors' support (certainly no and rather no). Admittedly, the result is not statistically significant, but, nearly a third of the opinions are sufficient for the system to respond with its incentives to improve the situation. This can be caused by a number of factors, 
Question 6: Do you feel your immediate supervisor' support for your further professional development?



1: Support for professional development provided by the superior

Source: Authors'own elaboration

such as the lack of superiors' interest, insufficient awareness of the offer of educational activities or fear that the subordinates will be off duty for some time and will not be able to perform tasks within the unit or also ignorance and unwillingness to support their surroundings in the development. This may sometimes stem from the personality traits of the respective leaders.

These findings support the efforts of the system for further education of the managerial staff within the courses organized in accordance with an appropriate commander's measure. The inclusion of a specific subject matter of how to support subordinates in their personality and professional development is more than desirable.



2: Support for professional development provided by the superior

Source: Authors'own elaboration

Question 8 is directly related to question 6. The results are presented in Fig. 3 and Fig. 4. A total of $43 \%$ of respondents state that their superior does not create conditions for their participation in professional training courses. The topic should be regularly included in the methodological meetings of the management due to getting feedback on whether the measures taken were reflected in respondents' opinions.

The answers to question 9 are related to the awareness of the offer of training activities within the unit. Information on educational activities is a fundamental prerequisite for employees to be able to consider the choice of activities they could participate in within their personality and

Question 8: Does your superior create conditions for your participation in further professional training courses?

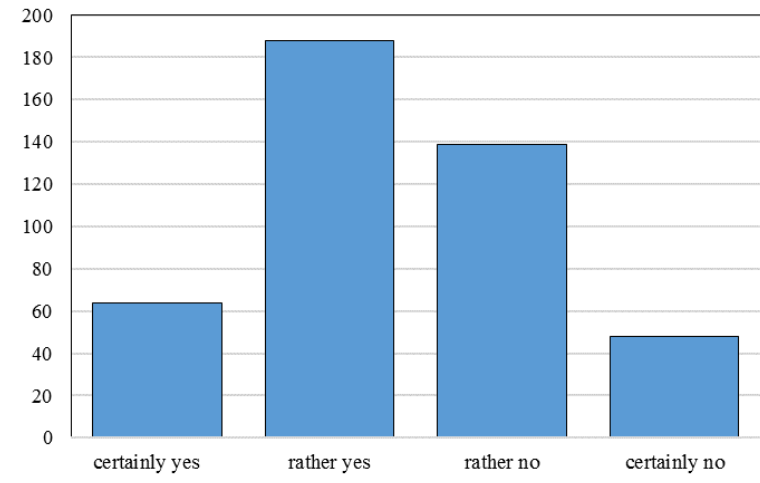

3: Creating conditions by the superior Source: Authors'own elaboration

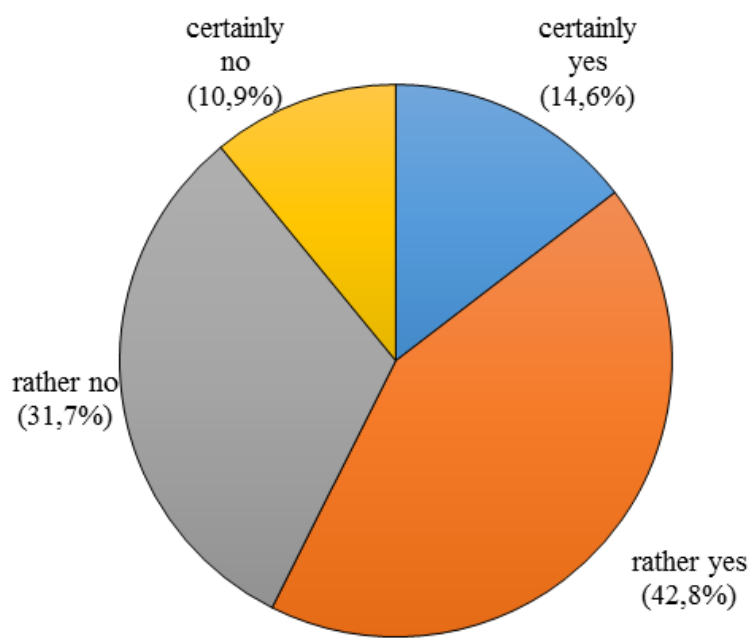

4: Creating conditions by the superior Source: Authors'own elaboration 
Question 9: Do you have enough information about the offer of further professional training courses organized by the Ministry of Defence?

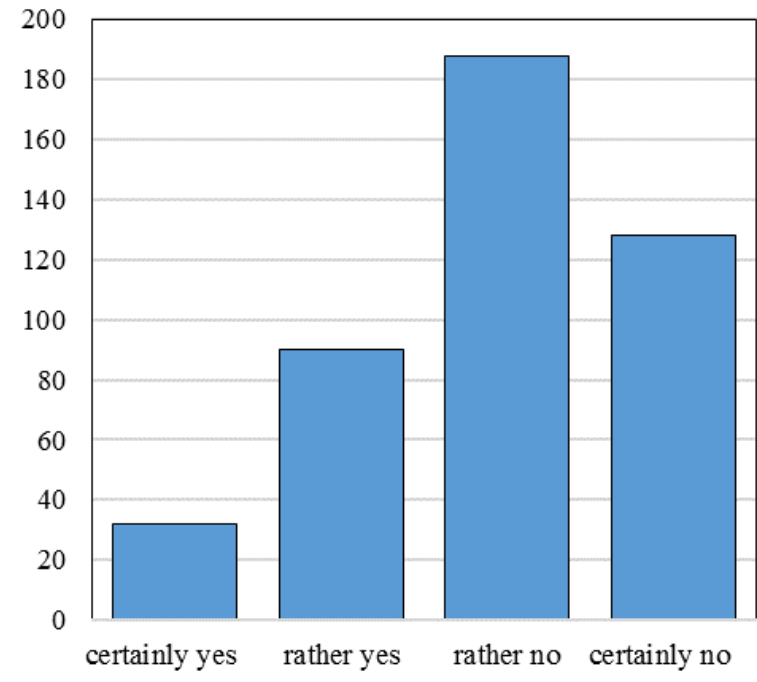

5: Awareness of the offer

Source: Authors'own elaboration

professional development. The research results are represented graphically in Fig. 5 and Fig. 6. A total of $72 \%$ of respondents do not have enough information about the offer of activities for further education within their profession (rather no and certainly no). This is a statistically significant finding, which indicates that information flows do not function optimally. It is possible to use various information boards, an information system for commanders (Staff Information System), etc. The offer is part of the organizational culture of each unit and facility and shows the quality of one of the important elements of its culture.

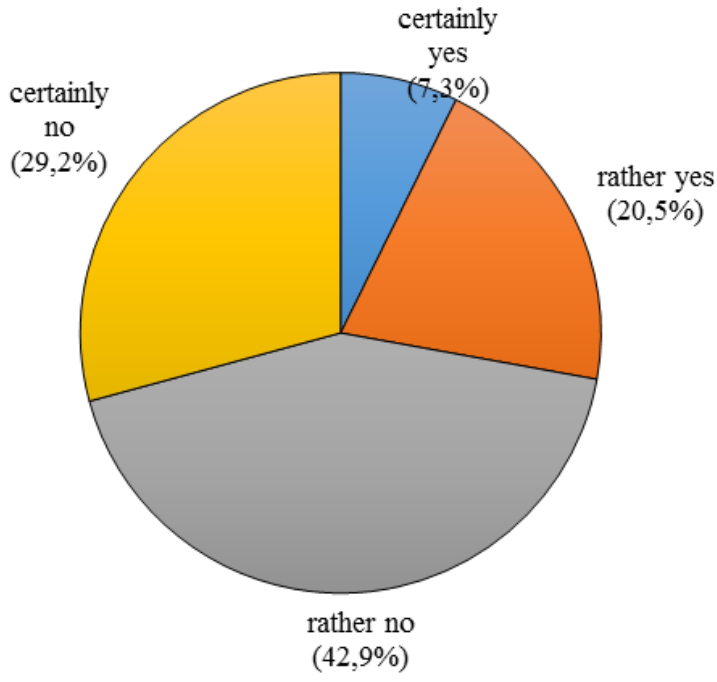

6: Awareness of the offer

Source: Authors'own elaboration

Question 12 shows the greatest obstacles that, according to respondents, preclude them from engaging in further professional training. The results are represented graphically in Fig. 7 and Fig. 8. Obstacles to the involvement show what obstructs respondents most to be actively involved in the process of further professional training. The time factor (36\%) and the disagreement of the superior (30\%) appear to be the biggest problems that, according to respondents, do not allow their involvement in further professional training.

In relatively young people creating the sample, the lack of time for further education can be understood with regard to the time and conditions

Question 12: Indicate what you consider to be the biggest obstacle to your participation in further professional training.

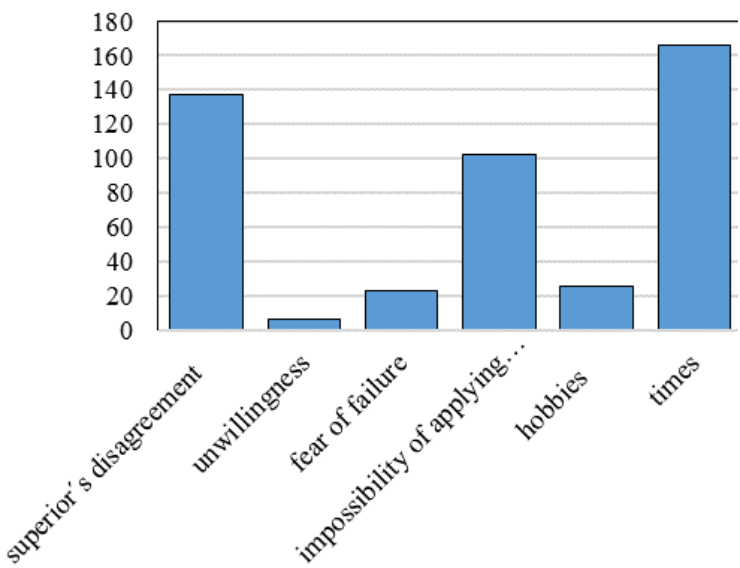

7: The biggest obstacle to participation Source: Authors'own elaboration

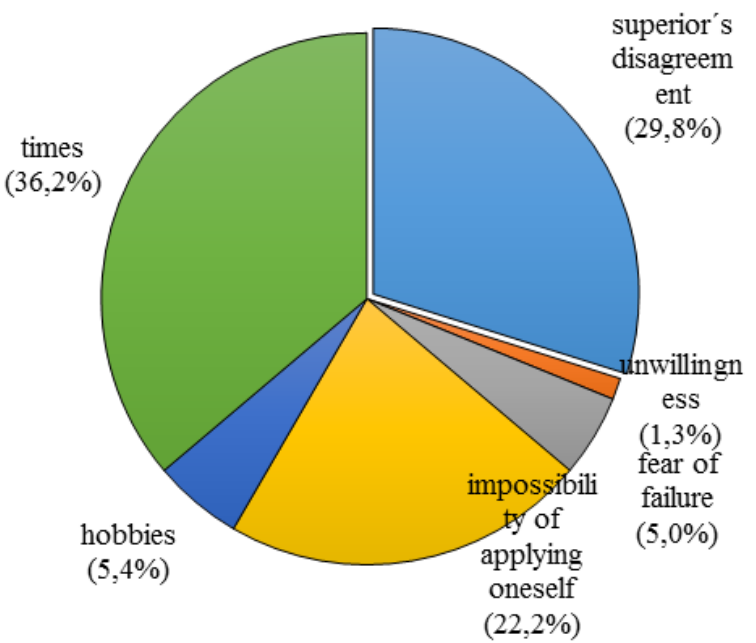

8: The biggest obstacle to participation Source: Authors'own elaboration 
today's young people live in and the problems, needs, etc. they have. It is an information burden due to using the Internet, the choice of information, the work on a mobile phone, obligations to work, family worries, etc. These are circumstances that may be used to even justify hypothetically that time is "the greatest enemy" for active involvement in further professional training.

There may be a number of reasons for the superior's disagreement. In the rare circumstances, the intention and the lack of interest in supporting a subordinate in the active participation in an educational activity cannot be excluded; these may sometimes be the so-called objective causes pertaining to "the participation in an activity in connection with the service within a service post" or another superior's disagreement or the missing capacity in the course, etc.

\section{Other Findings of the Research Done}

A total of $90 \%$ of respondents consider their participation in career training courses to be important (rather yes and certainly yes), which is a relatively encouraging finding, with regard to the importance of further staff training. The same percentage of respondents considers their knowledge to be sufficient (rather yes and certainly yes) to carry out activities within the service post. This may signal certain self-confidence in the issue of their readiness.

A total of $86 \%$ of respondents say that they are (rather and certainly actively) seeking opportunities to achieve continuous improvement in their expertise. A total of $14 \%$ of respondents are not (rather and certainly actively) seeking these opportunities. Admittedly, this is not statistically significant, but 62 respondents are not negligible data and it would be advisable to further investigate the causes of a rather passive approach to further education.

A total of 77 respondents state that they can apply the knowledge acquired in further professional training in their further work (rather yes and certainly yes). However, a total of 100 respondents maintain the contrary (rather no and certainly no). Therefore, the system should contemplate the content of further education so that those who will not be able to apply their knowledge within their service posts should be kept to a minimum.

A total of $70 \%$ of respondents state that they broaden their knowledge (rather yes and certainly yes) through self-study for performing their work activities. A total of 131 respondents maintain the contrary. Motivation to self-training is a task of commanders and other personnel within the units and facilities of the Army of the Czech Republic, e.g. by assigning motivational tasks, organizing informal meetings or, if need be, competitions, etc.

The offer of courses for further education is (rather and certainly) insufficient for 63\% of respondents. The remaining 37\% of respondents maintain the contrary. If this is the case, it would be advisable to revise the offer and to address the soldiers who should communicate their preferences in the field of further development in their profession. If the findings are of a reasonable value, the system should extend the offer or change its structure or the time possibilities of potential candidates' participation.

In the area of willingness to devote their personal time to self-study, respondents state as follows: a total of $45 \%$ of respondents are willing to devote the most of time, i.e. two to three hours, to self-study, $15 \%$ of respondents one hour and $14 \%$ of respondents more than 3 hours. A total of 31 respondents $(7 \%)$ are not willing to devote time to self-study at all.

Respondents consider the acquisition of new knowledge (62.5\%), the possibility of changing their assignment to a service post (30\%) and the extension of the employment relationship (26\%) to be decisive reasons for their involvement in further professional training; the superior's request $(12 \%)$ is considered to be the least important. In this question, it was possible to give more reasons; therefore, the sum of percentages is not 100.

As for the question what respondents consider to be the most important for the performance of their profession within the service post, they most often state professional, organizational and communication skills.

In the question where respondents get the most information about the offer of further professional education, respondents report they obtain the most information from their colleagues and superiors (93\%), out of which 55\% from their colleagues. There is an information system in the Army of the Czech Republic, which is used by $16 \%$ of respondents for this purpose; less than $14 \%$ of information is from personnel officers and 14\% from the Internet.

Only $8 \%$ of respondents (36) state they are not interested in further professional training. A total of $82 \%$ of respondents say they are willing to devote their free time to further professional training, while $18 \%$ are not (77).

Surprisingly, $60 \%$ of respondents state that the issue of further professional development was not discussed during their last performance appraisal.

\section{CONCLUSION}

The paper describes and explains the concept of competencies for lifelong learning. It defines learning competencies and the possibilities of their development. Each organization, including the military, 
must possess a system of further personnel development as one of its top priorities to be able to fulfil the requirements that it faces in the performance of tasks related to safeguarding defence and security. A system of further education has been created in the Army of the Czech Republic, which is designed as a system of various courses, trainings, stays abroad and other activities. These are formulated in the concept of staff development, which allows the staff to actively approach their self-development.

The research conducted, the results of which are selectively commented in the paper, shows that certain difficulties may occur in some factors, which respondents have accentuated in their statements. This does not mean that the system is not working. It would be appropriate to repeat the research and follow the questions mentioned in the context of time evolution. This may be a signal for the managerial staff to devote time and space to communicating with their subordinates, especially when conducting interviews within the service appraisal of soldiers.

Evaluating the involvement of staff and the quality of the activities related to further professional education should be a regular topic of meetings, workshops or conferences, where the representatives of brigades, the General Staff and the Ministry of Defence should also be invited. This could become an important motivating factor for the soldiers to perceive the necessity for their further professional development; however, they must have created conditions and necessary detailed information for that.

\section{Acknowledgements}

The paper has been elaborated within the framework of dealing with the long-term plan for an organization development entitled The Development of Social Competencies of a Soldier - Leader. Faculty of Military Leadership, University of Defence, Kounicova 65, 66210 Brno, Czech Republic.

\section{REFERENCES}

BELZ, H. and SIEGRIST, M. 2015. Key Competencies and their Development: Bases, Methods, Exercises and Games [in Czech: Klíčové kompetence a jejich rozvíjení: východiska, metody, cvičení a hry]. $3^{\text {rd }}$ Edition. Prague: Portal.

CHVÁL, M. and STRAKOVÁ, J. 2014. Possibilities of Measuring Learning Competencies - Application of a Finnish Tool in the Czech Environment [in Czech: Možnosti měření kompetencí k učení aplikace finského nástroje v českém prostředí]. Pedagogika, 64(3): 307-326.

ČIRJEVSKIS, A. 2015. Dynamic capabilities in abmidextrous organisation, decision making pattern for sustainable future. Entrepreneurship and Sustainability Issues, 3(2): 129-136.

DUBAUSKAS, G. and BALIUS, R. 2015. Management of public private partnership in education: aspects of public sector training sustainability issues. Journal of Security and Sustainability Issues, 4(4): 345-352.

DVOŘÁKOVÁ, Z. 2007. Human Resource Management [in Czech: Management lidských zdrojů]. Beck's Economic Textbooks. Prague: C. H. Beck.

HENDL, J. 2005. Qualitative Research: Basic Methods and Applications [in Czech: Kvalitativní výzkum: základní metody a aplikace]. Prague: Portal.

HURBIŠOVÁ, P. and DAVIDOVÁ, M. 2016. Towards enhanced security: education and development of military commanders within the Lithuanian and Austrian Armed Forces. Journal of Security and Sustainability Issues, 5(3): 311-322.

KIRCHHOFF, M. S. 1997.Competence as professional imperative: Does the Army promote competence in its officers? Master thesis. Kansas: Faculty of the U. S. Army Command and General Staff College.

KLIEME, E., MAAG-MERKI, K. and HARTIG, J. 2010. Competencies and their Importance in Education [in Czech: Kompetence a jejich význam ve vzdělávání]. Pedagogická orientace, 20(1): 104-119.

KUBEŠ, M., KURNICKÝ, R. and SPILLEROVÁ, D. 2004. Managerial Competencies: Competencies of Exceptional Managers [in Czech: Manažerské kompetence: způsobilosti výjimečných manažerů]. Prague: Grada.

LOKAJÍČKOVÁ, V. 2013. Learning Competency and Possibilities of its Development and Evaluation: definition of the concept and the overview of current approaches [in Czech: Kompetence k učení a možnosti jejího rozvíjení a hodnocení: vymezení pojmu a přehled současných přístupů]. Pedagogická orientace, 23(3): 318-341.

MINISTRY OF DEFENCE OF THE CZECH REPUBLIC. 2011. Concept of Staff Training of the MoD for 20122018 [in Czech: Koncepce prípravy personálu rezortu MO na období 2012-2018]. Prague: Ministry of Defence of the Czech Republic. 
MINISTRY OF DEFENCE OF THE CZECH REPUBLIC. 2019. Concept of Staff Training for the Needs of the MoD [in Czech: Koncepce prípravy personálu pro potreby rezortu MO]. Prague: Ministry of Defence of the Czech Republic.

PRAKAPIENE, D. and PETRONIS, V. 2015. Security enhancement factors: Naval force's officers' professional competence. Journal of Security and Sustainability Issues, 4(3): 209-220.

PRŮCHA, J. and VETEŠKA, J. 2014. Dictionary of Adult and Continuing Education [in Czech: Andragogický slovník]. $2^{\text {nd }}$ Edition. Prague: Grada.

RAUDELIŪNIENĖ, J., TUNČIKIENĖ, Ž. and PETRUSEVIČIUS, R. 2013. Competency assessment of professional military service in the Lithuanian Armed Forces. Journal of Security and Sustainability Issues, 3(1): 61-71.

RAZMA, G. 2019. A modern warfare paradigm: reconsideration of combat power concept. Journal of Security and Sustainability Issues, 8(3): 435-452.

ROSHA, A. and LACE, N. 2015. Sustainable development and behavioural patterns: to innovations through coaching. Journal of Security and Sustainability Issues, 5(2): 171-180.

SKALKOVÁ, J. 2018. Categories of goals, competences, their relationship and importance for the content of education in the context of the present [in Czech: Kategorie cíle, kompetence, jejich vzájemný vztah a význam pro obsah vzdělávání v kontextu současnosti]. Orbis scholae, 1(1): 7-20.

SMALIUKIENĖ, R., BEKEŠIENĖ, S. and PIOTROWSKA-TRYBULL, M. 2011. Sustainability Issues in the Military: Application of Computer-supported Collaborative Learning. Journal of Security and Sustainability Issues, 1(2): 123-131.

THE CENTER FOR ARMY LEADERSHIP. 2004. The US Army leadership field manual. Field Manual No. 22-100. New York: McGraw-Hill.

VETEŠKA, J. and TURECKIOVÁ, M. 2008. Competencies in Education [in Czech: Kompetence ve vzděláváni]. Prague: Grada.

VODÁK, J. and KUCHARČÍKOVÁ, A. 2007. Effective Employee Training [in Czech: Efektivní vzdělávání zaměstnanců]. Prague: Grada.

Contact information

L'ubomír Kubínyi: lubomir.kubinyi@unob.cz

Radomír Saliger: radomir.saliger@unob.cz 
